\title{
IDENTIFIKASI BAKTERI Coliform PADA AIR RENDAMAN TAHU YANG DIJUAL DI PASAR INDUK KOTA BANDUNG
}

\author{
Lola Malia Nurmalika ${ }^{1}$, Ria Khoirunnisa Apriyani ${ }^{2}$ \\ Program Studi D3 Analis Kesehatan (AKS), Politeknik Piksi Ganesha ${ }^{1,2}$ \\ lolamn03@gmail.com ${ }^{1}$, ria.khoirunnisa.19@gmail.com²
}

\begin{abstract}
Tofu soaking water is water that used as a marinade for tofu. Tofu has a high water and protein content, this causes tofu to be easily damaged and contaminated by bacteria. Coliform bacteria (fecal and nonfecal) are microbes that are indicators of pollution because the number of colonies must be positively correlated with presence of pathogenic bacteria. The purpose of this research was to determine the presence of Coliform bacteria in tofu soaking water in Bandung City Main Market using the Most Probable Number (MPN) method and what percentage. The type of research used is descriptive experimental. The population for this research were 15 tofu sellers in the Bandung City Main Market. The sample amounted to 5 samples of tofu soaked water with two repetitions taking into account the cloudy state of the tofu soaking water and negative control using sterile distilled water. Data analysis used the observation of coliform bacteria data from the results of research on tofu soaking water samples and then compared with the MPN table. The positive results of coliform bacteria based on the MPN test on 5 samples of tofu soaked water were indicated by gas formation in the durham tube on the presumptive test, the growth of brick-red colonies on the confirmed test, and gram-negative bacteria seen on the complementary test. Based on the results of the research that has been done, it can be concluded that 5 samples of tofu soaked water with each repetition twice were entirely (100\%) contaminated with Coliform bacteria.
\end{abstract}

Keywords : : coliform, most probable number (mpn), tofu soaking water

\begin{abstract}
ABSTRAK
Air rendaman tahu merupakan air yang digunakan sebagai rendaman pada tahu yang dijual. Tahu memiliki kandungan air dan protein yang tinggi, hal ini menyebabkan tahu mudah rusak dan terkontaminasi oleh bakteri. Bakteri Coliform (fecal dan non fecal) merupakan mikroba yang menjadi indikator pencemaran dikarenakan jumlah koloninya pasti berkolerasi positif dengan keberadaan bakteri patogen. Tujuan dari penelitian ini adalah mengetahui adanya bakteri Coliform pada air rendaman tahu yang dijual di Pasar Induk Kota Bandung menggunakan metode Most Probable Number (MPN) dan berapa persentasenya. Jenis penelitian yang digunakan adalah Deskriptif Eksperimental. Populasi untuk penelitian ini adalah 15 orang penjual tahu yang dijual di Pasar Induk Kota Bandung. Sampel berjumlah 5 sampel air rendaman tahu dengan masing-masing pengulangan dua kali dengan memperhatikan keadaan air rendaman tahu yang keruh dan kontrol negatif menggunakan aquadest steril. Analisis data menggunakan cara observasi memperlihatkan data jumlah bakteri coliform dari hasil penelitian pada sampel air rendaman tahu kemudian dibandingkan dengan tabel MPN. Hasil positif bakteri coliform berdasarkan uji MPN pada 5 sampel air rendaman tahu ditandai dengan terbentuk gas dalam tabung durham pada uji penduga, tumbuh koloni berwarna merah bata pada uji penguat, dan terlihat bakteri gram negatif pada uji pelengkap. Berdasarkan hasil penelitian yang telah dilakukan dapat disimpulkan bahwa 5 sampel air rendaman tahu dengan masing-masing pengulangan dua kali seluruhnya (100\%) terkontaminasi bakteri Coliform.
\end{abstract}

Kata Kunci : air rendaman tahu, coliform, most probable number (mpn)

\section{PENDAHULUAN}

Air adalah zat yang banyak ditemukan di bumi dalam bentuk uap, cair dan padat. Air adalah komponen kimia terbesar dalam makanan dan merupakan cairan penting bagi kehidupan. Air penting sebagai alat transportasi (nutrisi dan sisa metabolisme), reaktan dan media reaksi, stabilisasi (biopolimer, suhu), dan sebagai fasilitator 
sifat dinamik makromolekul, seperti enzim (Syah, 2020).

Tahu merupakan makanan olahan kedelai yang memiliki kandungan protein tinggi, dan harganya yang relatif terjangkau bagi masyarakat Indonesia. Produsen tahu di Pasar Induk Kabupaten Bandung didominasi oleh pengusaha kecil dan menengah, dimana aspek higiene dan sanitasi dalam kegiatan produksi sangat kurang diperhatikan. Tahu dengan kandungan protein sekitar $8 \%$ atau lebih menjadikan tahu sebagai media yang cocok untuk pertumbuhan bakteri. Tingginya tingkat populasi bakteri akan menyebabkan perubahan kualitas tahu, karena adanya metabolit yang dihasilkan selama pertumbuhan bakteri. Sumber kontaminasi bakteri pada air rendaman tahu dapat melalui kualitas air untuk perendaman tahu serta lingkungan produksi dan pekerja. Tanah dan air merupakan habitat alami bakteri, antara lain Escherichia coli, Staphylococcus aureus, Bacillus cereus, Coliform dan Salmonella sp. (Verawati et al., 2019)

Coliform adalah sekelompok bakteri yang digunakan sebagai indikator adanya pencemaran limbah dan kondisi yang tidak menguntungkan untuk air, makanan, susu dan produk susu. Coliform sebagai suatu kelompok dicirikan sebagai sekelompok bakteri aerobik fakultatif berbentuk batang, gram negatif, tidak membentuk spora, yang memfermentasi laktosa untuk menghasilkan asam dan gas dalam waktu 48 jam pada suhu $37^{\circ} \mathrm{C}$. Adanya bakteri coliform pada makanan dan minuman mengindikasikan kemungkinan adanya mikroba enteropatogenik dan toksigenik yang berbahaya bagi kesehatan, pada kondisi tertentu jika bakteri coliform pada tahu dengan kualitas hygiene yang kurang baik masuk ke dalam tubuh melebihi batas normal bisa menyebabkan penyakit seperti keracunan makanan, diare, pneumonia, dan infeksi saluran kemih (Jiwintarum et al., 2017)

Pemeriksaan yang dapat dilakukan untuk mengetahui adanya bakteri Coliform pada air rendaman tahu yang dijual di Pasar
Induk Kota Bandung dilakukan di laboratorium yaitu pemeriksaan bakteriologis menggunakan metode MPN yang terdiri dari 3 pengujian yaitu uji penduga menggunakan Media Briliant Green Lactose Broth (BGLB) dan tabung Durham. Tabung yang diduga mengandung bakteri Coliform menghasilkan gas karena fermentasi laktosa menghasilkan gas dan asam. Selanjutnya dilakukan uji penguatan pada media MacConkey Agar (MCA), ciri Coliform fekal berwarna merah bata dan Coliform non-fekal tidak berwarna merah bata. Pada uji pelengkap bakteri Coliform dibuat preparat dengan pewarnaan gram dan dilihat morfologinya di bawah mikroskop, ciri-ciri bakteri Escherecia coli adalah batang pendek berwarna merah (Suhartin, 2017)

Penelitian yang dilakukan oleh Malsin (2016) mengenai identifikasi bakteri Escherichia coli pada tahu yang dijual di Pasar Panjang Bonggoeya Kecamatan Wuawua menunjukkan bahwa 6 pedagang tahu $31 \%$ positif menjual tahu yang terkontaminasi bakteri Escherichia coli.

Penelitian yang dilakukan oleh Jayatno (2016) identifikasi bakteri Coliform pada deposit air minum isi ulang di Kecamatan Puuwatu Kota Kendari Sulawesi Tenggara menunjukkan bahwa sampel yang diambil sebanyak 12 atau (60\%) sampel positif terkontaminasi bakteri Coliform dan 8 atau ( $40 \%$ ) sampel negatif atau tidak terkontaminasi bakteri Coliform.

Penelitian yang dilakukan oleh Suhartin (2017) tentang identifikasi bakteri Coliform pada tahu yang dijual di Kota Kendari menunjukkan bahwa sampel yang diambil sebanyak 4 atau (80\%) sampel positif terkontaminasi bakteri Coliform dan 1 atau (20\%) sampel negatif atau tidak terkontaminasi dengan bakteri coliform. Penelitian ini bertujuan untuk mengetahui keberadaan bakteri coliform pada air rendaman tahu menggunakan metode MPN (Most Probable Number). 


\section{METODE}

Metode yang digunakan adalah MPN (Most Probable Number) menurut formula Thomas dengan ragaman 3 tabung yaitu uji penduga menggunakan media Briliant Green Lactose Broth (BGLB), selanjutnya uji penguat isolasi bakteri pada media MacConkey Agar (MCA) dan uji pelengkap membuat preparat menggunakan pewarnaan gram.

Penelitian ini dilakukan di Laboratorium Analis Kesehatan Politeknik Piksi Ganesha Bandung pada bulan Agustus 2021. Populasi dalam penelitian ini adalah 15 tempat penjual tahu yang dijual di Pasar Induk kota Bandung. Sampel dalam penelitian ini adalah 5 sampel air rendaman tahu dengan masing-masing $2 \mathrm{x}$ ulangan ditambah dengan kontrol negatif menggunakan aquadest steril, sampel air rendaman tahu yang diperoleh didapatkan dengan memperhatikan keadaan air rendaman tahu yang keruh.

Variabel bebas (independent) dalam penelitian ini adalah sampel air rendaman tahu yang dijual di Pasar Induk Kota Bandung. Sedangkan Variabel terikat (dependent) yang digunakan dalam penelitian ini adalah bakteri Coliform dalam sampel air rendaman tahu.

Pengumpulan data yang digunakan adalah data primer dengan objek berupa sampel air rendaman tahu yang diperoleh langsung dari lapangan. Data sekunder merupakan kumpulan data hasil penelitian pendahulu yang dijadikan referensi penulis yang berasal dari jurnal maupun buku-buku yang dipublikasi.

Analisis data dilakukan secara observasional, dengan memperlihatkan data dari jumlah bakteri yang didapat dari hasil pengamatan pada pemeriksaan sampel air rendaman tahu yang dijual di Pasar Induk Kota Bandung yang terkontaminasi bakteri coliform, kemudian dibandungkan dengan tabel MPN menggunakan 3 tabung atau menggunakan tabung 3 seri.

\section{HASIL}

Hasil Most Probable Number (MPN) Pada Uji Penduga, Uji Penguat, dan Uji Pelengkap pada Sampel Air Rendaman Tahu Yang Dijual Di Pasar Induk Kota Bandung

\section{Uji Penduga (Presumptive Test)}

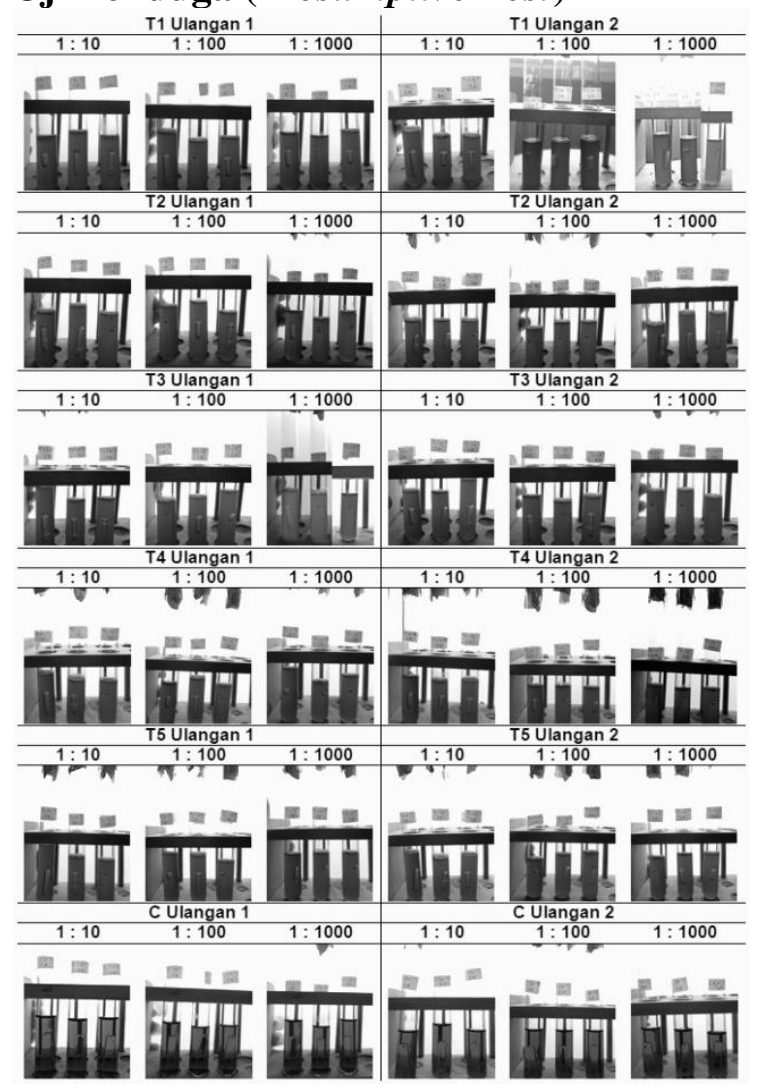

Gambar 1 Hasil positif uji penduga bakteri Coliform dari 5 sampel air rendaman tahu dengan $2 x$ pengulangan pada media Brilliant Green Lactose Broth (BGLB)

Berdasarkan penelitian yang telah dilakukan total bakteri Coliform (sel/100mL) yang di dapat dari rendaman air tahu yang dijual di Pasar Induk Kota Bandung hasilnya bervariasi. Pada penelitian ini dilakukan pengujian bakteri Coliform untuk mengetahui terbentuknya gelembung udara pada tabung durham. Setiap sampel terdri dari 9 tabung yang sudah ditanam dengan sampel air rendaman tahu dan diinkubasi selama $24-48$ jam pada suhu $35^{\circ} \mathrm{C}-37^{\circ} \mathrm{C}$. Pada gambar 1 sampel air rendaman tahu pada tabung dari 5 sampel 
dengan 2x ulangan T1 ulangan 1, T1 ulangan 2, T2 ulangan 1, T2 ulangan 2, T3 ulangan 1, T3 ulangan 2, T4 ulangan 1, T4 ulangan 2, T5 ulangan 1 dan T5 ulangan 2 rata-rata terbentuk gelembung udara pada tabung durham dan keruh, sedangkan pada tabung dari 2 sampel kontrol negatif $\mathrm{C}$ ulangan 1 dan $\mathrm{C}$ ulangan 2 tidak terbentuk gelembung udara dan tidak keruh.

Tabel 1 Hasil pengujian pada uji penduga menggunakan media pertumbuhan Brilliant Green Lactose Brorth (BLGB)

\begin{tabular}{|c|c|c|c|c|c|}
\hline \multirow{2}{*}{ Kode Sampel } & \multicolumn{3}{|c|}{$\begin{array}{l}\text { Jumlah tabung positif }(+) \\
\text { pada penanaman }\end{array}$} & \multirow{2}{*}{$\begin{array}{c}\text { Indeks } \\
\text { MPN } \\
\text { per } 100 \\
\text { mL }\end{array}$} & \multirow{2}{*}{ Keterangan } \\
\hline & $\begin{array}{l}1: \\
10\end{array}$ & $1: 100$ & $1: 1000$ & & \\
\hline T1 Ulangan 1 & 3 & 2 & 2 & 210 & Melewati batas cemaran / kualitas jelek \\
\hline T1 Ulangan 2 & 3 & 2 & 1 & 150 & Melewati batas cemaran / kualitas jelek \\
\hline T2 Ulangan 1 & 2 & 2 & 1 & 28 & Melewati batas cemaran / kualitas jelek \\
\hline T2 Ulangan 2 & 3 & 2 & 0 & 93 & Melewati batas cemaran / kualitas jelek \\
\hline T3 Ulangan 1 & 3 & 2 & 1 & 150 & Melewati batas cemaran / kualitas jelek \\
\hline T3 Ulangan 2 & 3 & 2 & 0 & 93 & Melewati batas cemaran / kualitas jelek \\
\hline T4 Ulangan 1 & 2 & 2 & 1 & 28 & Melewati batas cemaran / kualitas jelek \\
\hline T4 Ulangan 2 & 3 & 2 & 0 & 93 & Melewati batas cemaran / kualitas jelek \\
\hline T5 Ulangan 1 & 2 & 2 & 1 & 28 & Melewati batas cemaran / kualitas jelek \\
\hline T5 Ulangan 2 & 2 & 2 & 2 & 210 & Melewati batas cemaran / kualitas jelek \\
\hline C Ulangan 1 & 0 & 0 & 0 & $<3$ & Tidak melewati batas cemaran/ kualitas baik \\
\hline C ulangan 2 & 0 & 0 & 0 & $<3$ & Tidak melewati batas cemaran/ kualitas baik \\
\hline
\end{tabular}

Berdasarkan tabel 1 hasil pemeriksaan bakteri Coliform pada sampel air rendaman tahu yang dijual di Pasar Induk Kota Bandung pada media Brilliant Green Lactose Broth (BGLB) dari 5 sampel yang telah diulang $2 \mathrm{x}$ dan 2 sampel kontrol negatif menggunakan aquadest steril dinyatakan adanya gas pada tabung durham dan bersih pada kontrol negatif, dimana diperoleh indeks MPN T1 Ulangan 1: 210, T1 Ulangan 2: 150, T2 Ulangan 1: 28, T2 Ulangan 2: 93, T3 Ulangan 1: 150, T3 Ulangan 2: 93, T4 Ulangan 1: 28, T4 Ulangan 2: 93, T5 Ulangan 1: 28, T5 Ulangan 2: 210, C Ulangan 1: <3, C Ulangan 2: <3. Dari ke 10 sampel air rendaman tahu dinyatakan melewati batas cemaran, sedangkan 2 sampel kontrol negatif yang menggunakan aquadest steril tidak melewati batas cemaran.

\section{Uji Penguat (Confirmed Test)}

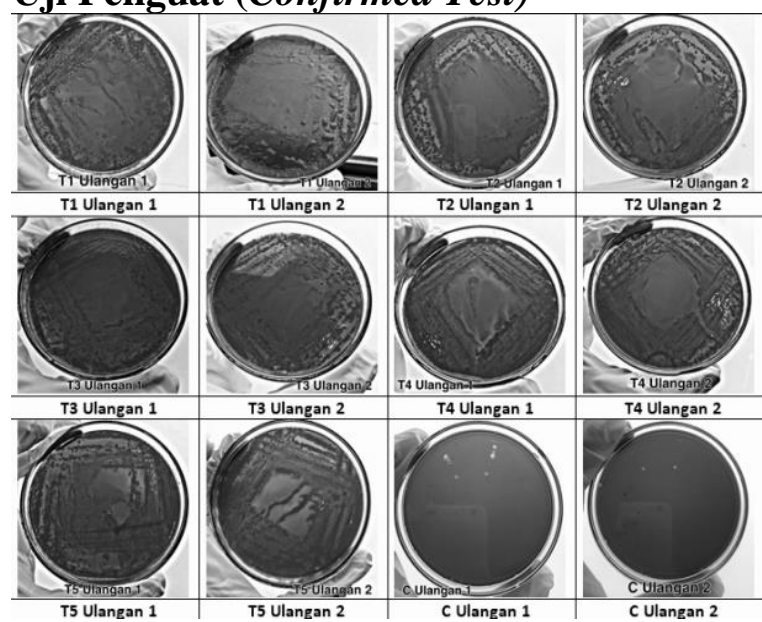

Gambar 2 Hasil inokulasi bakteri coliform pada media MCA

Pada uji penguat ini dilakukan pengujian bakteri Coliform yang 
diinokulasikan pada media MacConkey agar (MCA) untuk mengetahui kemurnian bakteri Coliform sesuai dengan ciri-cirinya. Hasil pengamatan koloni yang dilakukan dengan metode streak plate pola kuadran seperti pada gambar 2 yaitu terlihat pertumbuhan bakteri dengan terbentuk koloni bakteri pada 5 sampel air rendaman tahu dengan masingmasing 2x ulangan T1 ulangan 1, T1 ulangan
2, T2 ulangan 1, T2 ulangan 2, T3 ulangan 1, T3 ulangan 2, T4 ulangan 1, T4 ulangan 2, T5 ulangan 1 dan T5 ulangan 2 koloni bakteri berbentuk bundar kecil, cembung dengan tepian rata dan berwarna merah muda hingga merah bata sedangkan pada 2 sampel kontrol negatif dari aquadest steril $\mathrm{C}$ ulangan 1 dan $\mathrm{C}$ ulangan 2 tidak tumbuh koloni bakteri.

Tabel 2 Hasil pengujian koloni bakteri coliform yang di inokulasi pada media MacConkey Agar (MCA)

\begin{tabular}{ccc}
\hline \hline Kode Sampel & Hasil & Identifikasi \\
\hline T 1 Ulangan 1 & Koloni Merah Muda - Merah Bata & Coliform Fecal \\
\hline T 1 Ulangan 2 & Koloni Merah Muda - Merah Bata & Coliform Fecal \\
\hline T 2 Ulangan 1 & Koloni Merah Muda - Merah Bata & Coliform Fecal \\
\hline T 2 Ulangan 2 & Koloni Merah Muda - Merah Bata & Coliform Fecal \\
\hline T 3 Ulangan 1 & Koloni Merah Muda - Merah Bata & Coliform Fecal \\
\hline T 3 Ulangan 2 & Koloni Merah Muda - Merah Bata & Coliform Fecal \\
\hline T 4 Ulangan 1 & Koloni Merah Muda - Merah Bata & Coliform Fecal \\
\hline T 4 Ulangan 2 & Koloni Merah Muda - Merah Bata & Coliform Fecal \\
\hline T 5 Ulangan 1 & Koloni Merah Muda - Merah Bata & Coliform Fecal \\
\hline T 5 Ulangan 2 & Koloni Merah Muda - Merah Bata & Coliform Fecal \\
\hline C Ulangan 1 & Tidak tumbuh bakteri pada media & \\
\hline C Ulangan 2 & Tidak tumbuh bakteri pada media & - \\
\hline \hline
\end{tabular}

Berdasarkan tabel 2 hasil pemeriksaan bakteri Coliform pada air rendaman tahu yang dijual di Pasar Induk Kota Bandung pada uji penguat menggunakan media MacConkey Agar (MCA) 5 sampel air rendaman tahu masing-masing $2 \mathrm{x}$ ulangan dengan kode sampel T1 ulangan 1, T1 ulangan 2, T2 ulangan 1, T2 ulangan 2, T3 ulangan 1, T3 ulangan 2, T4 ulangan 1 , T4 ulangan 2, T5 ulangan 1 dan T5 ulangan 2 dinyatakan positif bakteri Coliform fecal ditandai dengan koloni berwarna merah muda-merah bata dan 2 sampel kontrol negatif aquadest steril $\mathrm{C}$ ulangan 1 dan $\mathrm{C}$ ulangan 2 tidak tumbuh koloni bakteri.

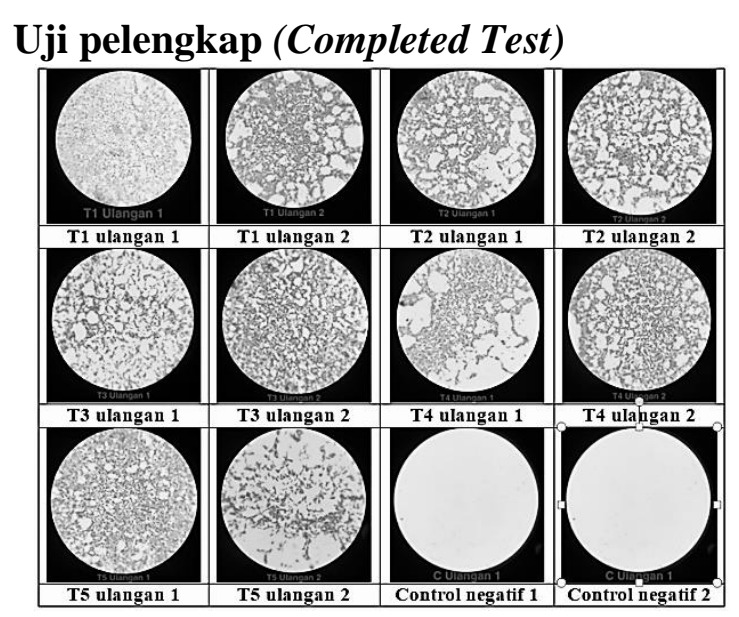

Gambar 3 hasil pewarnaan gram pada mikroskop peresaran 1000x 
Berdasarkan hasil penelitian pada gambar 3 menunjukkan bakteri yang dikultur pada media MacConkey Agar (MCA) adalah bakteri Coliform yang berbentuk batang (basil) berwarna merah. Bakteri tersebut merupakan bakteri gram negatif. Pada pewarnaan gram, bakteri gram negatif akan menghasilkan warna merah yang disebabkan sedikitnya kandungan peptidoglikan pada dinding sel bakteri sehingga zat warna gentian violet akan luntur oleh alkohol $95 \%$ dan akan menyerap zat warna carbol fuchsin sehingga bakteri akan berwarna merah. Pada gambar 3.4 preparat bakteri setelah dilakukan pewarnaan lalu dilihat dibawah mikroskop dengan perbesaran 1000x pada 5 sampel air rendaman tahu dengan masing-masing ulangan 2x dari T1 ulangan 1, T1 ulangan 2, T2 ulangan 1, T2 ulangan 2, T3 ulangan 1, T3 ulangan 2, T4 ulangan 1, T4 ulangan 2, T5 ulangan 1 dan T5 ulangan 2 terlihat sel bakteri berbentuk batang dan berwarna merah yang berarti bakteri tersebut adalah bakteri gram negatif, sedangkan pada 2 sampel $\mathrm{C}$ ulangan 1 dan $\mathrm{C}$ ulangan 2 tidak ada sel bakteri terlihat pada lapang pandang mikroskop.

\section{PEMBAHASAN}

Penelitian yang telah dilakukan adalah identifikasi bakteri Coliform pada air rendaman tahu yang dijual di Pasar Induk Kota Bandung. Pengambilan sampel air rendaman tahu dilakukan secara aseptik dengan menyiapkan wadah baru yang steril dan memakai APD yang memadai kemudian dibawa ke laboratorium untuk diperiksa.

Media yang digunakan dalam penelitian ini adalah Brilliant Green Lactose Broth (BGLB) yang merupakan media selektif yang mengandung garam empedu dan berwarna hijau brillian. Kedua zat tersebut dapat menghambat pertumbuhan bakteri gram positif, sehingga hanya bakteri gram negatif yang memfermentasi laktosa dan menghasilkan gas saja yang dapat tumbuh, termasuk Coliform menurut Suhartin (2017)Pada gambar 1 terdapat hasil uji penduga (presumptive test) pada media BGLB dimana hasil uji menunjukan bahwa bakteri Coliform tumbuh pada tabung durham yang mengandung gas atau gelembung udara dan kekeruhan setelah diinkubasi selama 24 jam pada suhu $37^{\circ} \mathrm{C}$, dari 5 sampel air rendaman tahu dengan masing-masing ulangan $2 \mathrm{x}$ dinyatakan melewati batas cemaran. Hal ini sesuai dengan yang dikemukakan oleh Widyaningsih (2016) bahwa sampel air rendaman tahu yang sudah diamati mempunyai hasil positif jika pada tabung durham terdapat gelembung udara yang menandakan keberadaan bakteri Coliform.

Media yang dipakai selanjutnya sebagai uji penguat adalah Mac Conkey Agar (MCA), dimana media ini mengandung laktosa, kristal violet dan neutral red bile salt yang mampu menghambat pertumbuhan bakteri gram positif menurut (Sari et al., 2019). Hal ini menyebabkan tidak semua bakteri dapat tumbuh dengan baik sehingga media ini dapat digunakan secara khusus untuk mengidentifikasi bakteri gram negatif. Pada gambar 2 terdapat hasil uji koloni bakteri Coliform dimana menunjukkan bahwa bakteri yang tumbuh memiliki morfologi yang sesuai dengan ciri-ciri yaitu koloni berbentuk bulat, cembung dan berwarna merah. Hal ini sesuai dengan yang dikemukakan oleh (Darna et al., 2018) bahwa koloni bakteri coliform berbentuk bulat, berukuran kecil, berwarna merah, permukaan cembung dengan tepian rata.

Pada gambar 3 terdapat hasil uji pelengkap yaitu melihat morfologi secara mikroskopis pada bakteri Coliform menggunakan pewarnaan gram dengan hasil gram negatif yaitu berwarna merah dan berbentuk batang (basil) dalam rantai pendek . Pada saat pewarnaan bakteri gram negatif akan kehilangan zat pewarna kristal violet setelah dicuci dengan alkohol, dan sewaktu diberi zat pewarna tandingannya yaitu dengan zat pewarna air fuchsin atau safranin akan tampak berwarna merah, hal ini disebabkan karena peptidoglikan bakteri yang tipis dan lapisan lemak yang tebal pada bakteri (Arianda, 2016). 
Hasil pengamatan pada tabel 1 menunjukkan bahwa sampel air rendaman tahu di Pasar Induk Kota Bandung mengandung bakteri Coliform dengan menggunakan metode MPN sebagai kontrol atau pembandingan untuk uji sampel air rendaman tahu. Kontaminasi utama pada produk tahu adalah kedelai dan air yang digunakan dalam pengolahan, masalah sanitasi juga menjadi masalah besar dalam menentukan mutu tahu. Terjadinya kenaikan jumlah mikroba selama penyimpanan disebabkan karena perendaman yang tidak diganti, sehingga mikroba yang ada dalam air perendaman dapat berkembang biak dengan baik.

Melihat adanya bakteri Coliform tersebut, dapat berbahaya bagi kesehatan tubuh dan dapat menimbulkan penyakit. Karena semakin tinggi tingkat cemaran kontaminasi bakteri Coliform, semakin tinggi pula resiko kehadiran bakteri patogen lain Suhartin (2017). Untuk menjamin kesehatan lingkungan dengan tersedianya air berkualitas baik, ditetapkan peraturan menteri kesehatan Republik Indonesia (Permenkes.RI)

Nomor 492/Menkes/SK/IV/2010 yang meliputi berbagai persyaratan salah satunya persyaratan mikrobiologis, yaitu tidak adanya bakteri Coliform sebagai indikator pencemaran pada setiap $100 \mathrm{~mL}$ sampel air yang dinyatakan dengan 0 colony forming unit $(\mathrm{cfu}) / 100 \mathrm{~mL}$.

Berdasarkan penelitian yang telah dilakukan tentang identifikasi bakteri Coliform pada air rendaman tahu yang dijual di Pasar Induk Kota Bandung didapatkan hasil nilai MPN yang tinggi. Hal ini menunjukkan tingginya tingkat cemaran air rendaman tahu. Beberapa faktor yang dapat mempengaruhi tingginya nilai MPN dan tingkat pemcemaran air rendaman tahu, yaitu air yang digunakan oleh pedagang, kebersihan wadah air rendaman, dan tempat berjualan pedagang tahu. Nilai MPN yang sangat tinggi ditujukkan oleh sampel T1 ulangan 1 dan T5 ulangan 2. Dari hasil observasi di lapangan, peneliti melihat sampel tersebut airnya sangat keruh yang sangat memungkinkan terkontaminasi oleh bakteri Coliform. Untuk bakteri Coliform kadar maksimum yang diperbolehkan dalam air minum adalah 0 MPN/100mL, keberadaan bakteri ini dalam air rendaman tahu dapat membahayakan kesehatan dan dapat menjadi patogen penyakit seperti diare, disentri atau kolera.

\section{KESIMPULAN}

Berdasarkan hasil penelitian yang telah dilakukan, dapat disimpulkan bahwa sampel air rendaman tahu dari 5 sampel dengan masing-masing dua kali ulangan menggunakan metode MPN tahap pertama pada media Brilliant Green Lactose Broth (BGLB) terjadi kekeruhan dan rata-rata adanya gelembung udara atau gas pada tabung durham, sedangkan pada sampel kontrol negatif aquadest steril tidak terjadi kekeruhan dan tidak ada gelembung udara, Nilai MPN yang diperoleh berdasarkan sampel positif menurut tabel MPN menggunakan 3 tabung yaitu 210, 150, 28, $93,150,93,28,93,28,210,<3,<3$, selanjutnya pada tahap kedua inokulasi hasil positif pada media MacConkey Agar (MCA) dari 10 sampel air rendaman tahu diperoleh koloni berwarna merah yang menandakan bakteri Coliform fecal, dan 2 sampel kontrol negatif tidak tumbuh koloni bakteri, selanjutnya pada tahap ketiga pewarnaan gram pada 5 sampel air rendaman tahu $2 \mathrm{x}$ ulangan ditemukan adanya bakteri berbentuk batang berwarna merah ini menunjukkan bahwa bakteri Coliform tersebut adalah bakteri gram negatif, sedangkan pada 2 sampel kontrol negatif aquadest steril tidak ditemukan bakteri. Pada sampel air rendaman tahu yang dijual di Pasar Induk Kota Bandung yaitu 5 sampel air rendaman tahu dengan masing-masing pengulangan dua kali seluruhnya (100\%) terkontaminasi oleh bakteri Coliform.

\section{UCAPAN TERIMAKASIH}

Penulis sampaikan ucapan terimakasih kepada Ibu Ela Melani, M.Si selaku Kepala Program Studi Analis Kesehatan Politeknik 
Piksi Ganesha, serta Ibu Ria Khoirunnisa Apriyani, S.Si, M.Si selaku Dosen Pembimbing atas bimbingan dan dukungannya kepada penulis dalam menyelesaikan artikel ilmiah, dan kepada pihak kampus yang telah memberikan izin menggunakan laboratorium Analis Kesehatan sebagai tempat penelitian penulis dalam menyelesaikan artikel ilmiah ini. Oleh karena itu, penulis sangat mengapresiasi dan berterimakasih kepada seluruh pihak yang membantu kelancaran pembuatan karya ilmiah ini.

\section{DAFTAR PUSTAKA}

Arianda, D. (2016). Buku Saku Bakteriologi. Am : Publishing.

Darna, Turnip, M., \& Rahmawati. (2018). Identifikasi Bakteri Anggota Enterobacteriaceae pada Makanan Tradisional Sotong Pangkong. Jurnal Labora Medika, 2(2), 6-12.

http://jurnal.unimus.ac.id/index.php/JL abMed

Jayatno, L. O. (2016). Identifikasi Bakteri Koliform Pada Air Depot Air Minum Isi Ulang Di Kecamatan Puuwatu Kota Kendari Sulawesi Tenggara. Karya Tulis Ilmiah. Kendari : Kementrian Kesehatan Republik Indonesia Politeknik Kesehatan Kendari Jurusan Analis Kesehatan. 23(45), 5-24.

Jiwintarum, Y., Agrijanti, \& Septiana, B. L. (2017). Most Probable Number (MPN) Coliform Dengan Variasi Volume Media Lactose Broth Single Strength (LBSS) Dan Lactose Broth Double Strength (LBDS). Jurnal Kesehatan Prima, 11(1), 12.

Malsin. (2016). Identifikasi Bakteri Escherichia Coli Pada Tahu Yang Dijual Di Pasar Panjang Banggoeya Kecamatan Wua-Wua. Karya Tulis Ilmiah. Kendari: Jurusan Analis Kesehatan Politeknik Kesehatan Kendari.

Sari, D. P., Rahmawati, \& W, E. R. P. (2019). Deteksi dan Identifikasi Genera Bakteri Coliform Hasil Isolasi dari
Minuman Lidah Buaya. Jurnal Labora Medika, 3(1), 29-35.

http://jurnal.unimus.ac.id/index.php/JL abMed

Suhartin, S. A. L. (2017). Analisis Bakteri Coliform Pada Air Rendaman Tahu Yang Di Jual Di Pasar Central Kota Kendari Provinsi Sulawesi Selatan. Karya Tulis Ilmiah. (Vol. 549). Kendari: Jurusan Analis Kesehatan Politeknik Kesehatan Kendari.

Syah, D. (2020). Buku Pengantar Teknologi Pangan (1st ed.). IPB Press.

Verawati, N., Aida, N., \& Aufa, R. (2019). Analisa Mikrobiologi Cemaran Bakteri Coliform Dan Salmonella Sp Pada Tahu Di Kecamatan Delta Pawan. Jurnal Teknologi Agro-Industri, 6(1), 61. https://doi.org/10.34128/jtai.v6i1.90 